\title{
PENGARUH AKTIVITAS BELAJAR SISWA DALAM MODEL PEMBELAJARAN KOOPERATIF TERHADAP HASIL BELAJAR GEOGRAFI DI SMAN 1 CEPIRING KABUPATEN KENDAL
}

\author{
Taqorrub Ubaidillah
}

Jurusan Tadris Ilmu Pengetahuan Sosial, Fakultas Tarbiyah dan Ilmu Keguruan, Institut Agama Islam

Negeri Ponorogo, Jl. Pramuka 156, Po. Box 116 Ponorogo 63471,

taqorrub@gmail.com

\begin{abstract}
ABSTRAK
Penelitian ini dilaksanakan di SMAN 1 Cepiring tahun 2020. Tujuan penelitian ini adalah 1) Untuk mengetahui tingkat aktivitas belajar siswa dalam model kooperatif pada pembelajaran geografi di SMAN 1 Cepiring Tahun 2020, 2) Untuk mengetahui seberapa besar pengaruh aktivitas belajar siswa dalam model kooperatif terhadap hasil belajar geografi di SMAN 1 Cepiring tahun 2020. Populasi dalam penelitian ini adalah seluruh siswa kelas X SMAN 1 Cepiring yang terdiri dari enam kelas tahun ajaran 2019/2020. Teknik pengambilan sampel menggunakan sampel acak dengan memakai lotre atau undian (random sampling) karena kelas dianggap homogen dan yang terpilih adalah kelas X-1 dan X-2. Variabel yang diukur adalah aktivitas belajar siswa dalam model pembelajaran kooperatif dan hasil belajar geografi. Analisis data yang digunakan adalah analisis deskriptif persentase dan analisis regresi ganda. Hasil penelitian diperoleh gambaran bahwa aktivitas siswa dalam model pembelajaran kooperatif dalam kategori tinggi. Sedangkan untuk pengujian hipotesis melalui analisis regresi ganda memperoleh hasil yakni adanya pengaruh yang signifikan antara aktivitas belajar siswa dalam model pembelajaran kooperatif terhadap hasil belajar geografi, dalam hal ini pengaruhnya dalam kategori tinggi.
\end{abstract}

Kata kunci: pengaruh; aktivitas belajar siswa; model pembelajaran kooperatif; hasil belajar geografi

\begin{abstract}
The research was done at SMAN 1 Cepiring in 2020. The purpose of this study is 1) To determine the level of student learning activities in the cooperative model of geography learning in SMAN 1 Cepiring in 2020, 2) To find out how much influence the learning activities of students in the cooperative model on geography learning outcomes at SMAN 1 Cepiring in 2020. Population in this study were all students of class X SMAN 1 Cepiring consisting of six classes in the academic year 2019/2020. The sampling technique uses a random sample by using a lottery (random sampling) because the class is considered homogeneous and the selected class X-1 and X-2. The variables measured were student learning activities in cooperative learning models and geography learning outcomes. Analysis of the data used is descriptive analysis of percentages and multiple regression analysis. The results obtained by the description that the activities of students in the cooperative learning model in the high category. Whereas for testing the hypothesis through multiple regression analysis the results obtained are that there is a significant influence between student learning activities in the cooperative learning model of learning outcomes in geography, in this case the effect is in the high category.
\end{abstract}

Keywords: influence; student learning activities; cooperative learning models; geography learning outcomes

\section{PENDAHULUAN}

Aktivitas merupakan suatu kegiatan atau tingkah laku yang dilakukan oleh seseorang. Aktivitas yang dilakukan oleh siswa dalam proses pembelajaran dinamakan aktivitas belajar siswa. Aktivitas belajar siswa tidak hanya dilakukan di sekolah, tetapi juga di rumah. 
Aktivitas belajar di sekolah bisa berlangsung di dalam kelas maupun di luar kelas, dan yang akan diteliti adalah aktivitas belajar di kelas. Sedangkan aktivitas belajar di rumah juga bisa berlansung di dalam ruangan rumah maupun di luar ruangan rumah.

Berdasarkan observasi lapangan di SMAN 1 Cepiring pada bulan Oktober-Desember 2019 fakta menunjukkan bahwa: 1) Hasil belajar geografi sebelum diterapkannya model pembelajaran kooperatif di sekolah tersebut rata-rata 65 sedangkan setelah diterapkannya model pembelajaran kooperatif hasil belajar geografi rata-rata 75, 2) Rata-rata nilai siswa untuk mata pelajaran geografi sudah mencapai Kriteria Ketuntasan Minimal (KKM). Hal ini menunjukkan adanya peningkatan hasil belajar geografi di sekolah tersebut, namun yang menjadi permasalahan dalam penelitian ini adalah apakah peningkatan hasil belajar tersebut disebabkan oleh diterapkannya model pembelajaran kooperatif atau disebabkan oleh faktor lain.

Pembelajaran kooperatif merupakan strategi pembelajaran yang mendorong siswa bekerja sebagai sebuah tim untuk menyelesaikan suatu tugas, atau mengerjakan sesuatu untuk mencapai tujuan bersama lainnya. Sistem pengajaran cooperative learning bisa didefinisikan sebagai sistem kerja/belajar kelompok yang terstruktur. ${ }^{1}$ Siswa belajar dalam kelompok kecil yang kemampuannya heterogen. Dalam menyelesaikan tugas kelompok, setiap anggota saling bekerja sama dan membantu dalam memahami suatu bahan ajar. Selama kerja kelompok, tugas anggota kelompok adalah mencapai ketuntasan materi dan saling membantu teman sekelompok dalam mencapai ketuntasannya. ${ }^{2}$

Untuk mencapai hasil yang maksimal, lima unsur model pembelajaran kooperatif harus diterapkan yaitu: saling ketergantungan, tanggung jawab perseorangan, tatap muka, komunikasi antar anggota, dan evaluasi proses kelompok. Langkah-langkah model pembelajaran kooperatif terdiri dari enam fase yaitu: menyampaikan tujuan dan memotivasi siswa, menyajikan informasi, mengkoordinasi siswa kedalam kelompok kooperatif, membimbing kelompok bekerja dan belajar, evaluasi, dan memberikan penghargaan. ${ }^{3}$

Hasil belajar merupakan perubahan perilaku yang diperoleh peserta didik setelah mengalami kegiatan kegiatan belajar. Perolehan aspek-aspek perubahan perilaku tersebut tergantung pada apa yang dipelajari oleh peserta didik. ${ }^{4}$ Benyamin S. Bloom menyampaikan tiga taksonomi yang disebut ranah belajar, yaitu: 1) Ranah kognitif berkaitan dengan hasil berupa pengetahuan, kemampuan dan kemahiran intelektual, 2) Ranah afektif berkaitan dengan perasaan, sikap, minat dan nilai, 3) Ranah psikomotorik berkaitan dengan kemampuan fisik seperti kemampuan motorik dan syaraf, manipulasi objek dan koordinasi syaraf.

Ketiga ranah ini menjadi objek penelitian hasil belajar. Penilaian ranah kognitif dilakukan dengan tes tertulis. Aspek psikomotorik lebih menekankan pada praktek dan aktivitas siswa. Penilaian dapat dilakukan pada saat proses belajar berlangsung dengan lembar observasi. Penilaian pada aspek afektif dilakukan dengan menggunakan angket/kuesioner.

\footnotetext{
${ }^{1}$ Lie, A. (2008). Cooperative Learning: Mempraktikkan Cooperative Learning di Ruang-ruang Kelas. Jakarta: Grasindo

${ }^{2}$ Slavin, R.E. (2008). Cooperative Learning Teori, Riset dan Praktik. Bandung: Nusa Media

${ }^{3}$ Trianto. (2007). Model Pembelajaran Inovatif Berorientasi Kontruktivisme. Jakarta: Prestasi Pustaka Publisher

${ }^{4}$ Anni, T.C. dkk. (2006). Psikologi Belajar. Semarang: UPT UNNES Press
} 


\section{METODE PENELITIAN}

Penelitian ini dilaksanakan di SMAN 1 Cepiring pada semester genap tahun ajaran 2019/2020. Populasi dalam penelitian ini adalah seluruh siswa kelas X yang berjumlah 240 siswa dan tersebar dalam 6 kelas dari kelas X-1 sampai dengan kelas X-6. Teknik pengambilan sampel dalam penelitian ini dilakukan dengan menggunakan random sampling, yaitu teknik pengambilan sampel secara acak. Dalam penelitian ini, peneliti mengambil sampel sebanyak dua kelas, yaitu kelas X-1 dan X-2.

Variabel dalam penelitian ini terdiri dari: (1) Variabel bebas, aktivitas belajar siswa dalam model pembelajaran kooperatif, Variabel terikat, hasil belajar geografi. Pengambilan data penelitian dilakukan dengan metode observasi dan dokumentasi. Sebelum instrumen digunakan maka terlebih dahulu dilakukan uji coba untuk mengetahui normalitas dan validitas.

Teknik analisis yang digunakan dalam penelitian ini adalah menggunakan analisis deskriptif persentase untuk mengetahui tingkat aktivitas belajar siswa dan analisis regresi ganda untuk mengetahui pengaruh aktivitas belajar siswa dalam model pembelajaran kooperatif terhadap hasil belajar geografi.

Analisis deskriptif persentase yang bertujuan untuk mengetahui variabel yang ingin diketahui, rumus yang digunakan untuk menghitung hasil observasi dengan menggunakan rumus:

$$
\text { Persentase }(P)=\frac{f}{\sum f} \times 100 \%
$$

Keterngan:

$P \quad:$ Persentase

$f \quad$ : Skor yang diperoleh

$\sum f \quad$ : Total skor yang diperoleh. ${ }^{5}$

Analisis regresi ganda digunakan untuk mengetahui besarnya pengaruh aktivitas belajar siswa dalam model pembelajaran kooperatif terhadap hasil belajar geografi. Dalam hal ini yaitu dengan menggunakan uji statistik dengan syarat data yang akan dianalisis berdistribusi normal. Uji statistik dalam hal ini adalah analisis regresi ganda dengan menggunakan program SPSS. Uji regresi ganda dengan rumus:

$$
R_{y}(1,2,3)=\frac{b_{1} \sum X_{1} Y+b_{2} \sum X_{2} Y+b_{3} \sum X_{3} Y+b_{4} \sum X_{4} Y+b_{5} \sum X_{5} Y+}{\sum Y^{2}}
$$

\footnotetext{
${ }^{5}$ Ali, M. (1984). Penelitian Kependidikan Prosedur dan Strategi. Bandung: Penerbit Angkasa
} 
Keterangan:

$R_{y} \quad$ : Koefisien regresi

$X \quad$ : Variabel bebas

$Y \quad$ : Variabel terikat. ${ }^{6}$

\section{HASIL DAN PEMBAHASAN}

Hasil penelitian siswa SMAN 1 Cepiring tentang besarnya aktivitas belajar siswa dalam model pembelajaran kooperatif, untuk lebih jelasnya dapat dilihat pada Tabel 1 dan Gambar 1.

Tabel 1. Distribusi Frekuensi Aktivitas Belajar Siswa dalam Model Pembelajaran Kooperatif

\begin{tabular}{|c|c|c|c|c|}
\hline \multirow{2}{*}{ No. } & \multirow{2}{*}{ Interval } & \multirow{2}{*}{ Kiteria } & \multicolumn{2}{|c|}{ Frekuensi } \\
\hline & & & $\mathbf{F}$ & $\%$ \\
\hline 1 & $12-21$ & Sangat rendah & 0 & 0 \\
\hline 2 & $21-30$ & Rendah & 22 & 27.5 \\
\hline 3 & $30-39$ & Tinggi & 42 & 52.5 \\
\hline 4 & $39-48$ & Sangat tinggi & 16 & 20 \\
\hline \multicolumn{3}{|r|}{$\sum$} & 80 & 100 \\
\hline \multicolumn{3}{|c|}{ Mean } & \multicolumn{2}{|c|}{33.325} \\
\hline
\end{tabular}

Sumber: Hasil Analisis Penelitian 2020

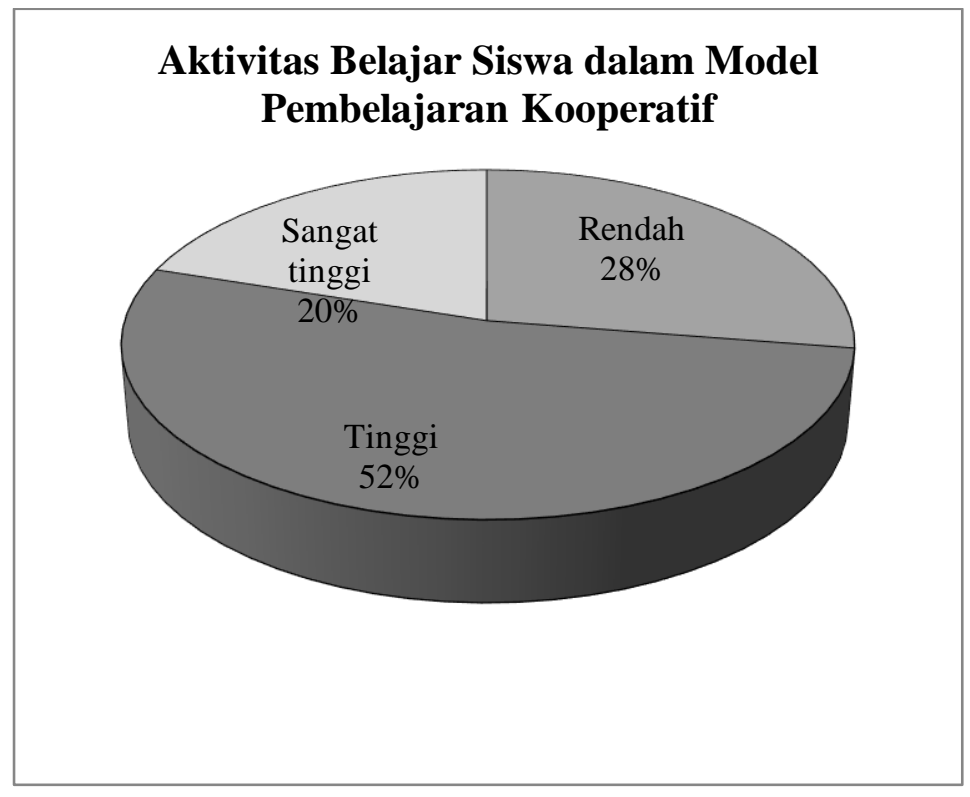

Gambar 1. Aktivitas Belajar Siswa dalam Model Pembelajaran Kooperatif

Berdasarkan tabel 1 dan gambar 1 diperoleh informasi bahwa 20\% siswa mempunyai aktivitas yang sangat tinggi dan 52\% mempunyai aktivitas yang tinggi, namun juga masih ada $28 \%$ siswa yang mempunyai aktivitas yang rendah. Hal ini juga dapat diketahui dari hasil perhitungan menunjukkan bahwa nilai skor rata-rata adalah sebesar 33,325 dan dengan

${ }^{6}$ Sugiyono. (2007). Metode Penelitian Kuantitatif Kualitatif dan R\&D. Bandung: Alfabeta 
kriteria yang ada maka secara umum dapat disimpulkan bahwa aktivitas siswa dalam model pembelajaran kooperatif tergolong tinggi.

Regresi ganda digunakan untuk mengetahui besarnya pengaruh antara aktivitas belajar siswa dalam model pembelajaran kooperatif terhadap hasil belajar geografi. Hasil analisis regresi ganda dengan menggunakan program SPSS dapat dilihat pada tabel 2.

Tabel 2. Analisis Regresi Ganda

Model Summary ${ }^{\text {b }}$

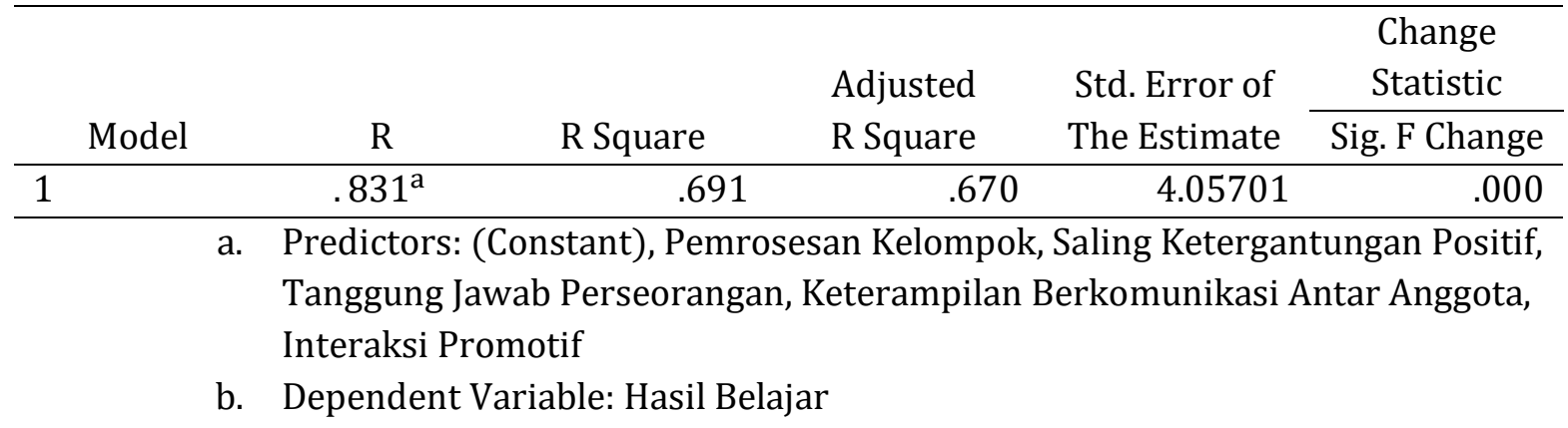

Sumber: Analisis Data SPSS 2020

Berdasarkan tabel 2 diperoleh R sebesar 0.691 yang berarti bahwa pengaruhnya tinggi antara aktivitas belajar siswa dalam model pembelajaran kooperatif terhadap hasil belajar geografi. Besarnya pengaruh dengan persentase $69 \%$ terhadap hasil belajar.

Model pembelajaran kooperatif merupakan suatu model pembelajaran yang membantu siswa dalam mengembangkan pemahaman dan sikap sesuai dengan kehidupan nyata di masyarakat, sehingga dengan bekerja secara bersama-sama diantara sesama anggota kelompok akan meningkatkan motivasi, produktivitas dan perolehan hasil belajar pada mata pelajaran geografi dengan standar kompetensi tertentu.

Hasil penelitian menunjukkan bahwa siswa di SMAN 1 Cepiring termasuk dalam kriteria tinggi. Dikatakan tinggi karena mayoritas siswa di SMAN 1 Cepiring bersungguhsungguh dan serius dalam proses pembelajaran menggunakan model pembelajaran kooperatif seperti aktivitas siswa dalam aspek saling ketergantungan positif, tenggung jawab perseorangan, interaksi promotif dan keterampilan berkomunikasi antar anggota, meskipun dalam aktivitas pemrosesan kelompok tergolong rendah. Namun setidaknya para siswa sudah berani berbicara untuk bertanya dan berusaha untuk mendengarkan apa yang telah dijelaskan oleh guru mereka.

Dalam model pembelajaran kooperatif aktivitas yang dilakukan oleh siswa yaitu: saling ketergantungan positif, tanggung jawab perseorangan, interaksi promotif dan keterampilan berkomunikasi antar anggota serta pemrosesan kelompok. Berdasarkan hasil dari penelitian aktivitas siswa dalam pemrosesan kelompok termasuk dalam kategori rendah. Hal ini dapat ditunjukkan bahwa ada beberapa siswa yang masih kurang serius dalam mendengarkan ketika guru sedang menjelaskan di depan kelas.

Berdasarkan hasil penelitian ini dapat diketahui bahwa terdapat pengaruh antara aktivitas belajar siswa dalam model pembelajaran kooperatif terhadap hasil belajar geografi. Hal ini dapat ditunjukkan dengan hasil analisis regresi ganda diperoleh R sebesar 0.691 yang berarti bahwa ada pengaruh antara aktivitas belajar siswa dalam model pembelajaran 
kooperatif terhadap hasil belajar geografi. Kontribusi aktivitas belajar siswa dalam model pembelajaran kooperatif terhadap hasil belajar geografi sebesar 69\%. Berdasarkan uji signifikansi dapat diperoleh uji $\mathrm{F}$ sebesar 33.099 dimana $\mathrm{F}_{\text {hitung }}>\mathrm{F}_{\text {tabel }}$ dengan taraf kesalahan 5\% yang berarti bahwa ada pengaruh yang signifikan antara aktivitas belajar siswa dalam model pembelajaran kooperatif terhadap hasil belajar geografi, sehingga hipotesis diterima.

Dengan demikian dalam kegiatan belajar, siswa yang mempunyai aktivitas belajar dalam model pembelajaran kooperatif yang tinggi maka juga dapat meningkatkan hasil belajarnya, sedangkan siswa yang memiliki aktivitas belajar rendah di dalam model pembelajaran kooperatif maka hasil belajarnya pun kurang maksimal. Proses belajar harusnya menimbulkan sikap aktif kepada siswa, dan salah satu cara yang ditempuh oleh siswa yaitu dengan meningkatkan aktivitas belajar siswa dalam model pembelajaran kooperatif di kelas sehingga hasil belajar pun akan menjadi lebih meningkat.

\section{PENUTUP}

Berdasarkan hasil analisis data dan pembahasan maka dapat disimpulkan sebagai berikut: (1) Aktivitas belajar siswa dalam model pembelajaran kooperatif dalam kategori tinggi. Hal ini disebabkan oleh faktor keseriusan siswa, kerajinan, kedisiplinan dalam belajar dan dari guru yang berkompeten terhadap mata pelajaran geografi, (2) Ada pengaruh yang signifikan antara aktivitas belajar siswa dalam model pembelajaran kooperatif terhadap hasil belajar geografi di SMAN 1 Cepiring. Kontribusi aktivitas belajar siswa dalam model pembelajaran kooperatif terhadap hasil belajar geografi sebesar 69\%. Hal ini disebabkan ratarata perolehan hasil belajar siswa sudah mencapai KKM.

Berdasarkan hasil kesimpulan yang diperoleh, maka saran/rekomendasi yang dapat disampaikan adalah: (1) Model pembelajaran kooperatif dapat meningkatkan hasil belajar siswa di SMAN 1 Cepiring, oleh karena itu pada materi-materi yang dapat diaplikasikan dengan model pembelajaran kooperatif sebaiknya guru menerapkan model pembelajaran tersebut sehingga hasil belajar dapat ditingkatkan, (2) Masih banyaknya guru-guru geografi yang menggunakan metode ceramah dalam menjelaskan materi, sebaiknya dibantu dengan media pembelajaran sehingga siswa akan mudah dalam memahami materi tersebut.

\section{DAFTAR PUSTAKA}

Ali, M. (1984). Penelitian Kependidikan Prosedur dan Strategi. Bandung: Penerbit Angkasa

Anni, T.C. dkk. (2006). Psikologi Belajar. Semarang: UPT UNNES Press

Lie, A. (2008). Cooperative Learning: Mempraktikkan Cooperative Learning di Ruangruang Kelas. Jakarta: Grasindo

Slavin, R.E. (2008). Cooperative Learning Teori, Riset dan Praktik. Bandung: Nusa Media

Sugiyono. (2007). Metode Penelitian Kuantitatif Kualitatif dan R\&D. Bandung: Alfabeta

Trianto. (2007). Model Pembelajaran Inovatif Berorientasi Kontruktivisme. Jakarta: Prestasi Pustaka Publisher 